\title{
The effect OD Fcorssword puzzle on the eighth grade students' reading comprehension of descriptive text at SMPN 1 Barat Magetan
}

\author{
Agustin Noni Munawaroh ${ }^{1}$, Lulus Irawati ${ }^{1}$, Arri Kurniawan' \\ ${ }^{1}$ Department of English Teaching, Universitas PGRI Madiun, Indonesia
}

\begin{tabular}{l}
\hline \hline Article Info \\
\hline Article history: \\
Received January 12, 2018 \\
Revised March 20, 2018 \\
Accepted Mei 29, 2018
\end{tabular}

\section{Keywords:}

Crossword Puzzle

Reading Comprehension Descriptive text

\begin{abstract}
The objective of this experimental research is to know whether or not there is an effect of using Crossword Puzzle on the Eighth grade students' Reading Comprehension of Descriptive texts at SMP Negeri 1 Barat. The researcher uses design True-experimental research in sub design The Randomized Posttest-Only Control Group Design. This research uses random sampling. The data collection method is test. The researcher uses primary data consisted of the students' scores collected by a Reading Comprehension. The researcher uses Pair-Sample t-test to know the result whether it was statistically significant. In research procedure the researcher uses planning, application, and reporting. The results of the research are that: (1) the procedures of teaching reading by using Crossword Puzzle consists of preparation and teaching and learning process. In preparation activities, the researcher prepares the material of descriptive text and RPP or lesson plan. In teaching and learning process, the researcher does three activities in two meetings. The first meeting, teaching a reading by using a conventional technique and the second meeting, by using a Crossword Puzzle. (2) The effect of using a Crossword Puzzle on the eighth grade students' reading comprehension of the descriptive text at SMP Negeri 1 Barat is significant. It can be seen from the significant value (2-tailed) of $\mathrm{T}_{\text {test }}$ that is 0.000 . It is lower than 0.05 . It means that the mean score of one class is different. The mean score of pretest is 55.7813 while the mean score of the post test is 96.7188. It means that a crossword puzzle is effective to teach a reading comprehension..
\end{abstract}

Copyright $(2) 2018$ Department of English Teaching. All rights reserved.

Corresponding Author:

Agustin Noni Munawaroh,

Department of English Teaching,

Universitas PGRI Madiun,

Jalan Setiabudi No.85 Madiun, Eas Java, Indonesia.

Email: nonimunawaroh@gmail.com

\section{INTRODUCTION}

In learning English, reading is the most important which must be mastered by students. Reading is about understanding written texts. It is a complex activity that involves both perception and taught. The students cannot get the information without reading because all of the information will be gotten students by reading fluently. According to Nunan (2003: 68), "Reading is defined as the ability to read at an appropriate rate with adequate comprehension". It means that reading is an activity where people or learners comprehend about what they read something. So that, in reading process the learners not only to know the meaning text but also on a comprehension in the meaning of a text. Reading needs a comprehension because reading related to constructing the meaning of content. It is supported by Moreillon (2007: 10) that, 
"Reading comprehension strategies are tools that proficient readers use to solve the comprehension problems they encounter in texts". It means that, by having comprehension, the students are able to make sense of what the texts tell about and the purpose is for the students to understand the written language. The students must concentrate on it, not only focus on the understanding meaning of content but also need to comprehend in some aspects such as: identifying topic, controlling idea, main idea, generic structure, language feature, vocabulary and grammatical structure. The good situation of the classroom is very needed by the teacher because the students can accept of what in reading and also can build the student's motivation to read in teaching and learning process. SMP Negeri 1 Barat is one of the Junior High School in Magetan Regency. From the result of observation during pre-research the problem in learning English, for some students is reading. This problem makes the students not interested in English during teaching and learning process. It indicates that there are students who have low motivation in reading English. This condition indicates that there are some students who have low ability in learning English vocabulary, the students who are not able to recognize the vocabulary are not be able to understand the text easily. To solve this problem the teacher should find effective various ways and teaching strategies to make the learners understand the lesson easily, so teaching learning process will not be bored. One of the techniques to increase skill reading the students is using Crossword puzzle.

This research was conformed with some previous research result by Nyoto (2015) who did classroom action research (CAR) which has four steps those are: Planning, Acting, Observing and Reflecting with the problem of research the use of Crossword puzzle Improve the Eighth Grade Students' Reading Comprehension by Using Crossword puzzle at SMP 1 Darusalam Jambearum Jember in the 2014/2015 academic year. To collect the data, the researcher uses interview and test method to get data about students' reading comprehension. The result of data that the reading test in the first cycle, showed that, there were 6 students or $30 \%$ of the students got score $\leq 65$. It means that not all the students got target score. Besides, there were 14 students or $70 \%$ of the students got score $\geq 65$. It means that not all of students achieved the target score. The result of students' reading test was reached the target score, the mean score is 66.75. Based on background above, an experimental research entitled "The Effect of Crossword Puzzle on the Eighth Grade Students' Reading Comprehension of Descriptive Texts at SMP Negeri 1 Barat”' was conducted.

\section{METHOD}

The researcher conducted the research March until July 2017. The researcher uses an experimental design. According to Creswell (2012: 294), "An experimental design is the traditional approach to conducting quantitative research". It means that an experimental design is traditional approach used to establish possible cause and effect between independent and dependent variables. One class was chosen as the experimental group and control group. The one class was selected by considering the scores of reading comprehension. Giving treatment to the experimental group, that was teaching reading using Crossword Puzzle, while the control group without treatment teaching reading using Crossword Puzzle. The researcher uses design True-experimental research in sub design The Randomized Posttest-Only Control Group Design because e both of group uses random sampling. It is supported by Creswell (2012: 309) that, "In true experiments, the researcher randomly assigns participants to different conditions of the experimental variable". Here, the individuals in the experimental group receive the experimental treatment, whereas those 
in the control group do not. Then both groups are post tested on the dependent variable. A diagram of this design as follows:

Table 1 The Randomized Posttest-Only Control Group Design

\begin{tabular}{cccc}
\hline Treatment group & $\mathrm{R}$ & $\mathrm{X}$ & $\mathrm{O}$ \\
\hline Control group & $\mathrm{R}$ & $\mathrm{C}$ & $\mathrm{O}$ \\
\hline
\end{tabular}

Note:

$\mathrm{X}$ : Exposure to the treatment.

$\mathrm{O}$ : Measurement of the dependent variable.

$\mathrm{R}$ : The Random assignment of individuals to groups.

$\mathrm{C}:$ The Control group.

(Fraenkel, 2012: 271)

In this research, the experimental group was taught reading by using crossword puzzle, while the control group was taught reading by using the conventional technique used by the teacher. To determine the experimental group and the control group, the researcher used a random sampling. The procedures of the research design were as follows:

1. Determining the experimental group and the control group using a random sampling.

2. Giving treatment to the experimental group, that was teaching reading comprehension using crossword puzzle, while the control group was taught reading using conventional technique used by the teacher as usually applied by the English teacher. In this research, the students were taught reading by the researcher.

3. The teaching learning process of reading was conducted in two meetings. Every meeting lasted for 80 minutes.

4. Giving the reading posttest to both groups to measure the students' reading comprehension after the treatments were given to the experimental group and control group was taught reading using conventional technique used by the teacher as usually applied by the English teacher.

5. Analyzing the results of reading posttest scores by using Independent Sample t-test with SPSS (Statistical Package for Social Science) version 17 to compare the result of the reading scores between the experimental group and the control group. The results were compared to see whether or not there was a significant effect of using crossword puzzle on the students' reading comprehension.

6. Drawing a conclusion from the result of the data analysis to answer the research problem.

The test which carried out in this research was reading post-test only. Based on Brown (2004: 3), test is a method which is done to measure a person's ability, knowledge and performance in a given domain. The researcher using descriptive text to know the students score of reading comprehension. After doing the test, it was found the reading test items were already available, so the reading test was given to both experimental and control groups. To analyzed the average scores using Independent Sample t-test with SPSS (Statistical Package for Social Science) version 17 to compare the result of reading scores between the experimental 
group and control group. The result were compared to see whether or not there was a significant effect of using crossword puzzle on students' reading comprehension.

Here, the researcher using Pair-Sample T Test. According to Yamin (2014: 56), "Pair-Sample T Test digunakan untuk membandingkan apakah terdapat perbedaan atau kesamaan rata-rata antara dua kelompok sampel data yang saling berkaitan/berpasangan". Thus, to know if there is any influence on eighth grade student's reading comprehension using crossword puzzle or not, the researcher used from the result PairSample $\mathrm{T}$ Test of pre test and post test. This research is calculated by using the Pair-Sample T Test as follows:

1. Open the data file which has inserted into SPSS Data Editor.

2. From the analyzing menu, choose sub-menu Compare Means, choose Pair-Sample T Test.

3. Then, fill both of variable into Paired variable.

4. Click OK

(Yamin, 2014: 57)

To know whether or not, there is a significant effect of using crossword puzzle on the eighth grade students' reading comprehension the analysis SPSS data output in Pair-Sample T-Test is test of Equality of Mean Score $\left(\mathrm{T}_{\text {test }}\right)$. The following are more detail explanations test is:

1. The equality of Mean Score $\left(T_{\text {test }}\right)$

Hypothesis:

$\mathrm{H}_{0}=$ The mean score of the one class is same

$\mathrm{H}_{1}=$ The mean score of the one class is not same

The criteria of taking decision for $\left(\mathrm{T}_{\text {test }}\right)$

a. $\mathrm{H}_{0}$ is accepted and $\mathrm{H}_{1}$ is rejected if the significant number is same or higher than 0,05. It means that the mean scores of pre-test and post-test is same.

b. $\mathrm{H}_{0}$ is rejected and $\mathrm{H}_{1}$ is accepted if the significant number is lower than 0,05 . It means that the mean scores of pre-test and post-test is not same.

\section{RESULT AND DISCUSSION}

The total number of the sample is 32 . The respondents of the experimental group and control group are the class of VIII F. Based on SPSS output, the result of main data, it can be seen in the following tables. There are three tables: Paired Samples Statistics, Paired Samples Correlations, and Paired Samples Test. The first table was "Paired Samples Statistics". It gives information descriptive statistics for two conditions.

Table 2 The Result of the SPSS Output (Table 1)

Paired Samples Statistics

\begin{tabular}{cccccc}
\hline & & $\mathrm{N}$ & Mean & Std. Deviation & Std. Error Mean \\
\hline \multirow{2}{*}{ Pair 1 } & Pre-test & 32 & 55.7813 & 7.52516 & 1.33027 \\
\cline { 2 - 6 } & Post-test & 32 & 96.7188 & 4.13665 & .73126 \\
\hline
\end{tabular}

According to the table above, it can be seen that the total number of the students $(\mathrm{N})$ for both pre-test and post-test is 32 students. The mean score of reading pretest (Mean) is 55.7813, while the post-test is 
96.7188. The spread of a group score is shown as the standard deviation (Std. Deviation). The standard deviation for pre-test is 7.52516, while the post-test is 4.13665. Then, the standard error mean (Std. Error Mean) for pre-test is 1.33027 , while the post-test is 0.73126 .

Table 3 The Results of the SPSS Output (Table 2)

\begin{tabular}{ccccc}
\hline \multicolumn{5}{c}{ Paired Samples Correlations } \\
\hline Pair 1 & $\mathrm{N}$ & Correlation & Sig. \\
\hline $\begin{array}{c}\text { Pre-test \& Post- } \\
\text { test }\end{array}$ & 32 & .163 & .374 \\
\hline
\end{tabular}

The second table in the SPSS Output tells that how two conditions relate to each others. Paired Samples Correlations show the Pearson correlation coefficient (with a two-tailed test of significance) for each pair of variables entered. The Paired Samples Correlations table adds the information that Reading comprehension pre-test and post-test scores are significantly and positively correlated $(\mathrm{r}=0.163)$.

Table 4 The Results of the SPSS Output (Table 3)

\begin{tabular}{|c|c|c|c|c|c|c|c|c|c|}
\hline & \multicolumn{9}{|c|}{ Paired Samples Test } \\
\hline & & \multicolumn{5}{|c|}{ Paired Differences } & \multirow{3}{*}{$\mathrm{t}$} & \multirow{3}{*}{ df } & \multirow{3}{*}{$\begin{array}{l}\text { Sig. } \\
(2- \\
\text { tailed } \\
\quad)\end{array}$} \\
\hline & & \multirow[t]{2}{*}{ Mean } & \multirow{2}{*}{$\begin{array}{c}\text { Std. } \\
\text { Deviati } \\
\text { on }\end{array}$} & \multirow{2}{*}{$\begin{array}{l}\text { Std. } \\
\text { Error } \\
\text { Mean }\end{array}$} & \multicolumn{2}{|c|}{$\begin{array}{l}\text { 95\% Confidence } \\
\text { Interval of the } \\
\text { Difference }\end{array}$} & & & \\
\hline & & & & & Lower & Upper & & & \\
\hline Pair 1 & $\begin{array}{c}\text { Pre- } \\
\text { test \& } \\
\text { Post- } \\
\text { test }\end{array}$ & 40.93750 & $\begin{array}{c}7.9755 \\
2\end{array}$ & $\begin{array}{c}1.4098 \\
9\end{array}$ & $\begin{array}{c}- \\
43.81298\end{array}$ & $\begin{array}{c}- \\
38.06202\end{array}$ & -29.036 & $\begin{array}{l}3 \\
1\end{array}$ & .000 \\
\hline
\end{tabular}

The third table is the most important table, as it contains the inferential t-test statistics. This table will help decide whether there is a statistical and significant difference between the conditions, and whether the null hypothesis can be rejected in favor of the research hypothesis. The Paired Samples Test gives the hypothesis test results. Based on the table above, the researcher has invented that the $t$-test is significant as the $\mathrm{p}$-value is less than 0.05 . This is reported as:

$$
t(31)=-29.036, p<0.001 \text {. }
$$

According to the output of the Paired Sample t-test of the scores of the reading test by using SPSS program, the significant value (2-tailed) is 0.000 . It is less than 0.05 . It can be said that in the significance level of $95 \%$, the null hypothesis which says "There is no effect of using a crossword puzzle on the eighth grade students' reading comprehension of the descriptive text at SMP Negeri 1 Barat" is rejected. Therefore, the alternative hypothesis which says "There is an effect of using a crossword puzzle on the eighth grade students' reading comprehension of the descriptive text at SMP Negeri 1 Barat" is accepted.

The result shows the students of the experimental class who has been taught a reading by using a crossword puzzle, they get better scores on the reading comprehension test than the students who do not get any treatment. It can be seen from the significant value (2-tailed) of $\mathrm{T}_{\text {test }}$, that is 0.000 . It is lower than 0.05. It means that the mean score of one class (the experimental class and control class) is different. Then, based on the Table 1, the mean score of the experimental class is 96.7188 and that of the control class is 55.7813. It proves that there is a mean score is difference between the experimental group and the class 
group. It means that a crossword puzzle is effective to teach a reading comprehension. The research hypothesis in this research which says "There is an effect of using a crossword puzzle on the eighth grade students' reading comprehension of the descriptive text at SMP Negeri 1 Barat" is accepted.

Based on the results, it is effective to use a crossword puzzle on the eighth grade students' reading comprehension. It implies that using a crossword puzzle can be used in the future reading activity. It can be seen from the students' reading scores of the students which is significantly different from the post-test. There are many reasons that a crossword puzzle is effective in students' reading comprehension. Using crossword puzzle the students acquire the habits of collective decision making, making differences between similar words, developing the continuity of thought. McKeachie (2002) in Jaramillo, et al (2012: 214) suggests some advantages in the use of games like a crossword puzzle solving because students play an active role, make decisions, solve problems, and react to the results of their own decisions.

The procedures which are followed in administering the crossword puzzle are effective ways to increase the students' learning. Weisskirch (2006) in Tricia M, et al (2009: 9) is found that the students are more likely to complete the puzzles when being given the time to do them in class, and when being given the chance to work collaborating with others, the students find that the puzzles are more useful and enjoyable than when doing them by themselves. Thus, learning can become a positive experience. Crossword puzzles are generally associated with game playing, fun, and recreation, and therefore can be less intimidating for the students than other activities. The research outcome also supports some previous research results about the use of a crossword puzzle which proves that they are appropriate to enhance the students' reading comprehension. For example an action research that was done by Nyoto (2015). He finds that the use of a crossword puzzle is effective to teach a reading comprehension class. It can be seen from the first cycle, it is shown that the result of students' reading test reaches the target score, the mean score is 66.75. Whereas, in the second cycle the result of students' reading test reaches the target score, the mean score is 73.00 .

Although the result of this research is successful, there are some weaknesses found in this research. Firstly, it is difficult for the students in comprehending the words in the text. They depend on the dictionaries. Secondly, there are some students who are confused in the opposite and similar meaning of the words. They think that the similar and opposite meanings of the words which have the same meanings, so they should find the synonyms of the words. Thirdly, only some students both in the experimental and the control group who pay much attention to the lesson. Fourthly, the mean scores of the students in the control class are lower than the passing grade of the English subject of the school, that is 75 . However, after giving the treatment by using a crossword puzzle, the scores of students' reading comprehension increase, the mean score is 96.7188 .

Despite the weaknesses, a crossword puzzle is suitable for teaching a reading comprehension for all of the levels of the students. Based on the result and the discussion, a crossword puzzle gives an effect on the eighth grade students' reading comprehension at SMP Negeri 1 Barat. The result of the study shows the significant difference on the means of the two groups and the sig. value is lower than $\mathrm{p}$ value .05. There are many reasons that a crossword puzzle in students' reading comprehension is an effective tool in learning and teaching process. A Crossword puzzle acquires the habits of a collective decision making, achieves durability in learning, gets a high degree of interest, increases understanding and also supports a vocabulary building. 


\section{CONCLUSION}

Based on the results of the data analysis, the hypothesis verification and the discussion in the previous chapter, it could be concluded that the effect of using a crossword puzzle on the eighth grade students' reading comprehension of the descriptive text at SMP Negeri 1 Barat is significant. It means that the students in the experimental group who has been taught a reading by using crossword puzzle get better scores in the reading test than in the control group who has been taught a reading by using the conventional technique. The mean score of experimental group is 96.7188 while the mean score of the control group is 55.7813. Crosssword puzzle is suggested that teacher uses the media in teaching English especially in reading. The students should increase their speed reading skill, vocabulary and comprehend about text. The future research should conduct another research that has different perspective from this research. The institution build next competent researcher.

\section{REFERENCES}

Brown, H. D. (2004). Language Assessment: Principles and Classroom Practices. San Fransisco. California: Pearson Education

Creswell, J. W. (2012). Planning, Conducting,and Evaluating Qualitative Research (Fourth Edition). Boston: Pearson Education, Inc.

Davis, T.,M, Shepherd, B., \& Zwiefelhofer, T. (2009). Reviewing for Exams: Do Crossword Puzzles Help in the Sucess of Student learning?. The Journal of Effective Teaching, 9(3), 9. Retrieved from: http://uncw.edu/ctc/ET/articles/Vol9_3/Davis.pdf

Frankael, J. R., \& Wallen, N. E. (2012). How to Design and Evaluate Research in Education (Eighth Edition). New York: Mc Graw- Hill.

Jaramillo, C.,M, Losada, B.,M, \& Fekula, M.,J. (2012). Developments in Business simulation and experimental learning. Designing and Solving Crossword Puzzle: Examining Efficacy in a Classroom Exercise (Vol. 39, pp 214). Colombia.

Moreillon, J. (2007). Collaborative Strategies for Teaching Reading Comprehension: Maximizing your Impact. Chicago: American Library Association

Nunan, D. (2003). Practical english Language Teaching. New York: McGraw-Hill.

Nyoto, F. (2014). Improving the Eighth Grade Students' Reading Comprehension by Using Crossword Puzzle at SMPN Darusalam JemberArum. Thesis not Published. Jember. English Department.

Yamin, S. \& Kurniawan, H. (2014). SPSS Complete: Teknik Analisis Statistik Terlengkap dengan Software SPSS (Second Edition). Jakarta: Salemba Infotek. 